\title{
航空写真に基づいた交通流解析の一手法について \\ ON A METHOD OF TRAFFIC DATA ANALYSIS THROUGH AERIAL PHOTOGRAPHY
}

\author{
巻上安爾*・坂本破魔雄**・林昌親***
}

By Yasuji MAKIGAMI, Hamao SAKAMOTO and Masachika HAYASHI

\begin{abstract}
This report describes the outline and the results of a traffic survey on a 800 meter section of the Hanshin Expressway making use of areial photographs from a helicopter hovering at an altitude of about 800 meter. The objectives of the study are to record the traffic flow conditions at the time of congestion and to find out the cause of the congestion. The traffic in the study section was photographed by two $35 \mathrm{~mm}$ still camera evry five second for one hour. All the vehicles recorded in the south bound traffic flow were numbered and traced in order to depict the trajectories in the time and space diagram. The speed and density contour diagrams are depicted making use of the theory of three dimensional representation of traffic flow. The cause and conditions of the traffic congestion are investigated with these diagrams.
\end{abstract}

1. はじめに

都市高速道路, 都市間高速道路のいずれを問わず, 東 京や大阪などの大都市周辺の高速道路では, 膨大な交通 需要のために橴滞が頻発している．阪神高速道路におい ても交通渋滞が頻繁に起こっているが, 特に放射線下り 方向で発生した渋滞が，しばしば環状線にまで波及して 高速道路網全体の機能低下をもたらしかねない状況にま で至っている. 本調査研究は,このような渋滞が午前中 のピーク時に頻発している阪神高速道路堺線下り方向の 西大阪線合流部之津守入路合流部間の約 $800 \mathrm{~m}$ の区間 を対象として,ヘリコプターからの航空写真撮影, 路側 ビデオ撮影およびフローティングによる走行時間調査を 実施して, 調査対象区間における交通流の実態把握を行 うとともに, 調查対象区間から発生している交通渋滞の 発生のメカニズムを追求するため実施された.

\section{2. 調 查 概 要}

調査対象区間である阪神高速道路堺線の西大阪線合流

* 正会員 工博 立命館大学教授 理工学部土木工学科 ( ( 603 京都市北区等持院北町)

** 阪神高速道路公団業務部交通管制課長 ( T541 大阪市東区北久太郎町 4-68)

*** 学生会員 立命館大学大学院理工学研究科 ( $\mathbf{\% 6 0 3}$ 京都市北区等持院北町)

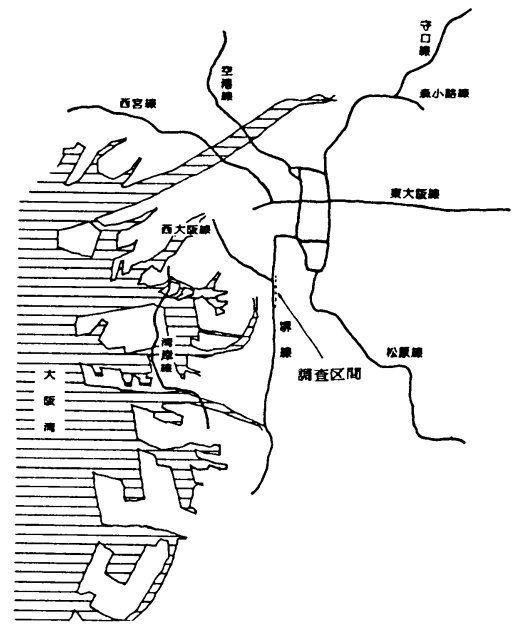

図一1 阪神高速道路概略図

部と津守入路間の高速道路網における位置を図一1に示 す.この調査区間は往復分離 4 車線で延長約 $800 \mathrm{~m}$ の 区間であるが, 午前 10 時以降この区間から渋滞が発生 し, 環状線方向へ渋滞が延伸していくため, 交通運用上 の対策を検討していくうえで渋滞発生のメカニズムを明 らかにしていくことが必要となった区間である，本調査 研究は、記調査区間を対象にヘリコプターからの上空固 
表一1 調査概要

\begin{tabular}{|c|c|c|c|c|}
\hline 項 & 人員 · 器 & 6 & 法 & 的 \\
\hline $\begin{array}{llll}\text { ピ } & \text { デオ } \\
& & \end{array}$ & $\begin{array}{l}\text { 調査員 } \\
\text { ビデオカメラ } \\
\text { ビデオデッキ } \\
\text { バッテリー } \\
\text { 三 脚 } \\
\text { タィマー }\end{array}$ & $\begin{array}{l}3 \text { 名 } \\
1 \text { 台 } \\
1 \text { 台 } \\
2 \text { 号 } \\
1 \text { 台 } \\
1 \text { 式 }\end{array}$ & 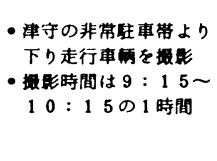 & $\begin{array}{l}\text { ・車線別、車程別の } \\
\text { 交通量の锤测を行なう }\end{array}$ \\
\hline $\begin{array}{l}\text { フローティング } \\
\text { 袢 查 }\end{array}$ & $\begin{array}{l}\text { 調相員 } \\
\text { テープレコーダー } \\
\text { カセットテーフ } \\
\text { ストップ・ウォッチ } \\
\text { 硙録用紙 } \\
\text { 作莱車(公団所有) }\end{array}$ & $\begin{array}{l}2 \text { 台 } \\
1 \text { 台 } \\
2 \text { ケ } \\
1 \text { ケ } \\
1 \text { 故 } \\
1 \text { 台 }\end{array}$ & $\begin{array}{l}\text { - } 100 \mathrm{~m} \text { 毎のキロポスト } \\
\text { 通過時刻を録音し、 } \\
\text { 平均走行速度の即定を } \\
\text { 行なう } \\
\text { - } 3 \text { 回のフローティング }\end{array}$ & $\begin{array}{l}\text { - 区間速度の分布状㫛、 } \\
\text { 旅行時間の実撯偪を } \\
\text { 得ろとと }\end{array}$ \\
\hline 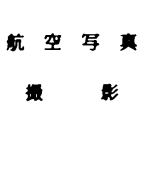 & 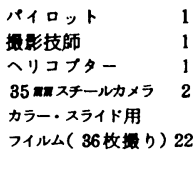 & $\begin{array}{l}1 \text { 名 } \\
1 \text { 名 } \\
1 \text { 機 } \\
2 \text { 台 } \\
22 \text { 本 }\end{array}$ & 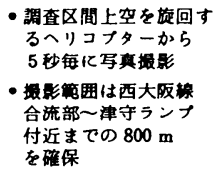 & $\begin{array}{l}\text { - 密度、速度の分布状況 } \\
\text { の把捯 } \\
\text { ・沾䓰状况の把握 }\end{array}$ \\
\hline
\end{tabular}

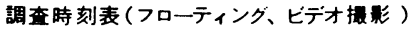

\begin{tabular}{|c|c|c|}
\hline $\begin{array}{r}\text { フローティング } \\
\text { 区 間 }\end{array}$ & \multicolumn{2}{|c|}{$\begin{array}{l}\text { 为見撟入口 }(1.8 \mathrm{kp}) \sim \\
\text { 玉出出口 }(5.4 \mathrm{kp})\end{array}$} \\
\hline \multirow{3}{*}{$\begin{array}{r}\text { フローティング } \\
\text { 時 刻 }\end{array}$} & 第 1 回 & $\begin{array}{l}9 \text { 時 } 15 \text { 分 } 43.47 \text { 秒 } \\
9 \text { 時 } 19 \text { 分 } 50.78 \text { 秒 }\end{array}$ \\
\hline & 第 2 回 & $\begin{array}{l}9 \text { 時 } 36 \text { 分 } 31.35 \text { 秒 } \\
9 \text { 時 } 41 \text { 分 } 05.98 \text { 秒 }\end{array}$ \\
\hline & 第 3 回 & $\begin{array}{l}10 \text { 時 } 02 \text { 分 } 53.57 \text { 秒 } \\
10 \text { 時 } 09 \text { 分 } 22.32 \text { 秒 }\end{array}$ \\
\hline ピデオ搌影時刻 & & 15 分 10 時 15 分 \\
\hline
\end{tabular}

定地点スチールカメラによる航空写真撮影を主に, 精度 チェックのための路側ビデオ撮影とフローティングによ る走行時間調査を実施したものである. 各調査の使用器 機や調査方法等の調査内容は表一1に示すとおりであ る. 調查は昭和 57 年 8 月 26 日（木曜日）午前 9 時 15 分から同 10 時 15 分までの 1 時間にわたつて実施され た. 調査当日は, 快晴に恵まれ視界, 路面状態ともに良 好で, 交通も通常の状態で流れていた。 しかしやや風が 強く, ホバリングをしながら撮影を続けるヘリコプタ一 が気流で流され気味のところがあったが, 以後の解析に は支障がなく調査は順調に行われた。

\section{3. 調査と集計の方法}

\section{（1）調查方法}

本調查研究のメインとなる航空写真撮影は調査区間西 側約 $1 \mathrm{~km}$ を大阪湾に向かって流れる木津川の上空 750 $\mathrm{m}$ でホバリングさせたヘリコプターに搭載した $35 \mathrm{~mm}$ スチールカメラを用いて行われた．使用したカメラは秒 単位で撮影時刻が画面上に記録されるようになってお り，撮影は 5 秒間隔で行われ，2台のカメラを用いて 9 時 15 分 01 秒から 10 時 16 分 43 秒までの間に 740 枚の スライドフィルムの撮影を行うことができた. また調査 に先だち $3.3 \mathrm{kp}, 3.6 \mathrm{kp}$ およ゙ $3.9 \mathrm{kp}$ の 3 地点の防音 壁に黄色の防災シートを張り付けて, フィルム画面上で キロポストの位置が明瞭に識別できるように隻備が行わ れている.

なお上記へリコプターからの航空写真撮影に併せて調 査区間の中間点にある津守の非常駐車帯から路側ビデオ 撮影を行うとともに, 調査区間を含む汐見橋入口から玉 出出口の間で調査時間内に 3 回のフローティング走行を 主として追越車線沿いに実施し，100 m ポストの通過時
刻をテープレコーダーに 録音している.これら 2 つの補助的調查は航空写 真撮影の解析結果の精度 を確かめると同時に調査 時の道路状況を全般的に 把握するために実施され たものである.その実施 状況を図一2に示す.

またこれらの実態調查 に併せて, 阪神高速道路 交通管制システムを通じ て車両検知器からの 5 分 間交通量や渋滞状況等 の検知情報を入手してい る ${ }^{3)}$. 図一 3 に調査終了

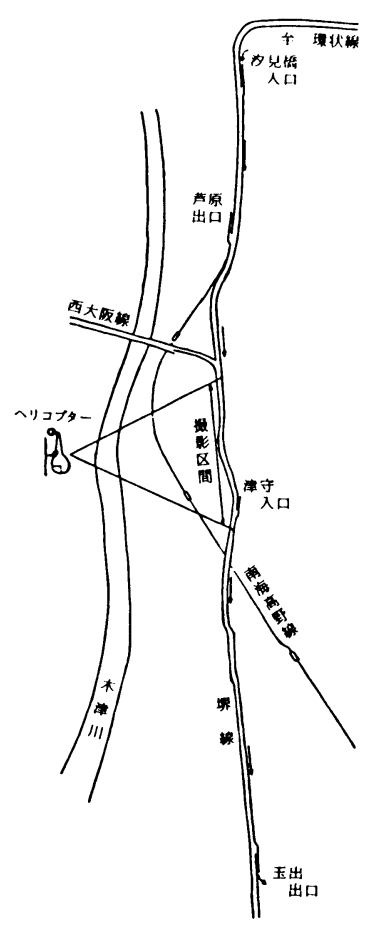

図一2 フローティングコース および調查時刻表

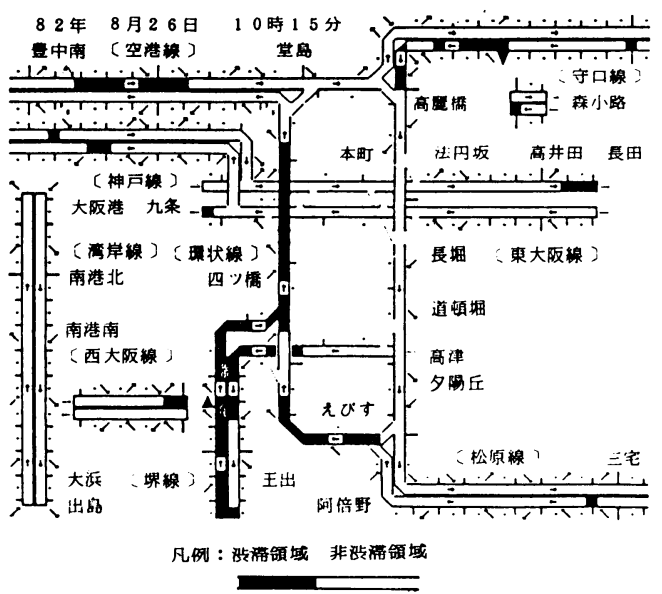

図一3 調査終了時刻における啮滞長データ 
時刻の渋滞状況を示す.同図は交通管制システムからの ハードコピーであり 5 分ごとのアウトプットも入手して いる.

\section{（2）集計方法とその結果}

渋滞状況データによると調査当日午前 9 時 45 分から 堺線下り方向において津守入口を頭とする延長約 $500 \mathrm{~m}$ の渋滞が発生し, 10 時 5 分には西大阪線に渋滞が及ん でいることが示されている．以下に述べる航空写真から のデー夕集計に多大の時間を要することが予想されたの で, 航空写真の解析対象時間を 30 分間とし, 上記の渋 滞状況から判断して午前 9 時 40 分から 10 時 10 分の 30 分間について集計を行った。

集計作業に入る前に, 航空写真フィルムのスライド投 影画面の大きさを定め,この拡大率に合わせたプリント を用意し，この画面にキロポストの位置を示す防災シー トやレーンマーク, 道路構造を目印にキロポストの位置 を明示したものを用意した。集計作業は航空写真フィル ムをスライドで投影し，プリントのキロポストを参考に スライド画面に $100 \mathrm{~m}$ ポストを設定し，画面上に映さ れた下り車線上を走行する全車両の撮影時刻毎の存在位 置を画面上にマークするとともに，計測対象となった車 両について車線別に調査区間への流入順に番号を付し， 撮影時刻とそのときの存在位置および車種を逐次記録用 紙に記入して行った。ただし存在位置の確定はスクリー ンに用いた白紙を撮影フレームごとに用意し，マークし たキロポストを基準に，プロットされた各車の位置をス ケールで読み取り $\mathrm{m}$ 単位で計測して求めたものである. 集計結果の例を表一2に示す.この集計表では走行・追 越の各車線に対して 60 台分の記録スペースが用意され ている. 各スペースの上段に観測区間への流入時に走行 していた車線の区分と車両番号を，下段に撮影時刻にお ける当該車両の存在位置をキロポストに対応させてメ一 トル単位で記録されている，なお車種については別途車
津守ランプ 至 玉出
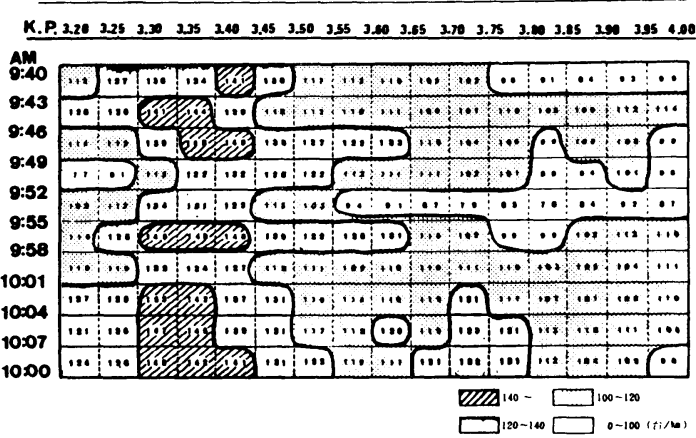

図一4 実測值による密度コンター図

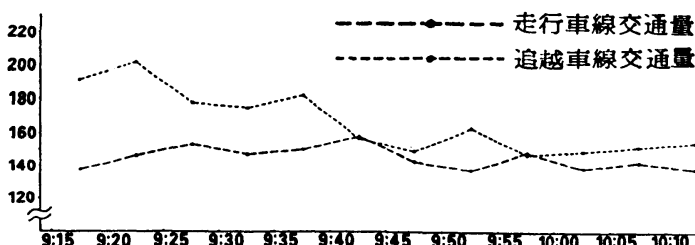

図一5 ビデオ搌影調査地点における 5 分間交通量变動図

両番号に対応させて集計表が用意されている．以上の計 測作業の結果を直接集計して解析対象時間帯について $50 \mathrm{~m} こ ゙ と の$ 交通密度を求め交通密度コンター図を作製 した．結果を図一4に示す．図から解析時間帯のほとん ビの部分で，西大阪線合流部に相当する $3.3 \mathrm{kp}$ から $3.5 \mathrm{kp}$ にかけて $50 \mathrm{~m}$ の測定区間内の存在台数が車線当 たりで 7 台以上, $\mathrm{km}$ 当たりに換算して 140 台 $/ \mathrm{km} / 2$ 車 線という高い交通密度となっており，西大阪線からの流 入交通による超過需要が，調査区間を頭とする渋滞の主 な原因ではないかと推測された。

なお路側ビデオ撮影の再生画面から直接通過車両台数 の計测を行っている，結果を図一5に示す，図によれば，

\section{表一2 車両存在位置計測集計表（例）}

フィルム番号, 626 , 撮影時刻 : 10 時 7 分 39 秒

\begin{tabular}{|c|c|c|c|c|c|c|c|c|c|c|c|c|c|c|c|c|c|}
\hline \multirow{6}{*}{$\begin{array}{l}\text { 走 } \\
\text { 行 合 } \\
\text { 計 } \\
\text { 車 } 52 \\
\text { 線 台 }\end{array}$} & 审 1 & $\begin{array}{l}\text { No } \\
\text { k p }\end{array}$ & 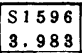 & $\begin{array}{l}51597 \\
3.966\end{array}$ & $\begin{array}{r}F 1023 \\
3.955 \\
\end{array}$ & $\begin{array}{l}51598 \\
3.943 \\
\end{array}$ & $\begin{array}{l}G 1281 \\
3.927 \\
\end{array}$ & $\begin{array}{l}51599 \\
3.903 \\
\end{array}$ & $\begin{array}{l}S 1600 \\
3.875 \\
\end{array}$ & $\begin{array}{l}S 16001 \\
8.861\end{array}$ & $\begin{array}{l}G 1283 \\
8.830 \\
\end{array}$ & $\begin{array}{l}G 1282 \\
3.815 \\
\end{array}$ & $\begin{array}{l}S 1602 \\
3.808 \\
\end{array}$ & $\begin{array}{l}51603 \\
3.792 \\
\end{array}$ & $\begin{array}{l}51604 \\
3.782 \\
\end{array}$ & $\begin{array}{l}\text { G1285 } \\
3.770 \\
\end{array}$ & $\begin{array}{l}S 1605 \\
3.761\end{array}$ \\
\hline & 車 & $\begin{array}{l}\text { No } \\
\text { kp }\end{array}$ & G 112884 & 51606 & S1607 & 51608 & G1287 & 51609 & 51610 & G1288 & $S 1611$ & G1286 & S1612 & 51613 & G1289 & S1614 & G1290 \\
\hline & 南 & $\frac{k p}{N o}$ & 3.751 & 3. 729 & 3.718 & 3. 710 & 3.688 & 3.668 & 3,643 & 3.623 & 3. 609 & 3,595 & 3.573 & 3,548 & 3.532 & 3.522 & 3,508 \\
\hline & & $\mathbf{k p}$ & 3.490 & 3,481 & $\begin{array}{l}51616 \\
3,458\end{array}$ & $\begin{array}{l}51617 \\
3,437\end{array}$ & $\begin{array}{l}51618 \\
3.425\end{array}$ & G1292 & $\begin{array}{l}51619 \\
3.406\end{array}$ & $\begin{array}{l}51620 \\
8,384\end{array}$ & $\begin{array}{l}S 1621 \\
3.366\end{array}$ & $\begin{array}{l}51622 \\
3.354\end{array}$ & $\begin{array}{l}S 1623 \\
3.345\end{array}$ & $\begin{array}{l}S 1 \\
3\end{array} 624$ & $\begin{array}{l}51625 \\
3.327\end{array}$ & S 1626 & S 16227 \\
\hline & 車 & No & $S 1628$ & $S 1629$ & 51630 & 51631 & 51632 & 51633 & 51634 & & & & & & & & \\
\hline & & kp & 3,296 & 3,285 & 3,272 & 3,260 & 8.240 & 8.226 & 3.215 & & & & & & & & \\
\hline \multirow{7}{*}{$\begin{array}{l}\text { 追 } \\
\text { 越 } \\
\text { 合 } \\
\text { 計 } \\
\text { 䛲 } \\
\text { 線 台 }\end{array}$} & 車 1 & No & M1843 & M1844 & M1845 & M1846 & M1847 & M1848 & M1849 & M1850 & M1851 & M1852 & M1853 & M1854 & M1855 & M1856 & M1857 \\
\hline & & $k p$ & 3.992 & 3,982 & 8.955 & 3.943 & 8. 912 & 3.883 & 3.863 & 3.845 & 3.825 & 3.811 & 3,792 & 3,759 & 3.738 & 3.722 & 3,706 \\
\hline & 車 1 & No & M1858 & M1859 & M1860 & M1861 & M1862 & M1868 & M1864 & M1865 & M1866 & M1867 & M1868 & M1869 & M1870 & M1871 & M1872 \\
\hline & & KD & 3.696 & 3.681 & 3.661 & 3.640 & 8.617 & 3.605 & 3.584 & 3,569 & 3,549 & 3.534 & 3,517 & 3,500 & 3,486 & 3.475 & 3,464 \\
\hline & 車 1 & No & M1873 & M1874 & M1875 & M1876 & M1877 & M1878 & M1879 & M1880 & M1881 & M1882 & M1883 & M1884 & M1885 & M1886 & M1887 \\
\hline & & $\mathrm{kp}$ & 3.452 & 3,439 & 3,424 & 3.407 & 3,391 & 3,363 & 3.336 & 3.325 & 3.315 & 3.297 & 3. 289 & 3.274 & 3.261 & 3.245 & 3.232 \\
\hline & 苚 & $\begin{array}{l}\text { No } \\
\text { kp }\end{array}$ & $\begin{array}{l}M 1888 \\
3.223\end{array}$ & $\begin{array}{r}M 1889 \\
3,212\end{array}$ & $\begin{array}{l}M 1890 \\
3,204\end{array}$ & & & & & & & & & & & & \\
\hline
\end{tabular}

車No 頭部の記号

$\mathrm{S}$ : 観測区間へ流入時の走行位㯰が走行車䶂であった車両

G：西大阪線合流部から流入した車両

M：観測区間へ流入時の走行位䈯が追越車線であった車両

F : 津守ランプから流入した車両 
淡滞が始まる 9 時 40 分以前は追越車線の交通量が走行 車線のそれよりも 30 台 60台/5分も多いが, 9 時 40 分以降の渋滞発生以降は頭打ちとなり走行・追越両車線 ともに, 150 台/5分程度で安定した値を示すのが目立っ ている.

\section{4. 交通流の総合解析}

\section{（1）交通流の 3 次元立体モデル}

以下に筆者の一人が文献 3）ですでに公表している交 通流の 3 次元表示法について, その概要を示す。まず, 道路上を走行する車両に流入順に番号をつけていき, 道 路上のある点からの距離を $x$, 時間を $t$ にとった時間・ 空間平面に各車両の走行軌跡をプロットして, 走行軌跡 図を求めることができる. いまこの走行軌跡図に第 3 番 目の座標軸として累積台数 $n$ を加えることにより, 交 通流を 3 次元の立体的な表面として表現することが可能 である.ただし現実の交通流では個々の車両の走行速度 が異なり追越が頻繁に起こる.すすかち図一6の点線に 示されるように速度の異なる車両の軌跡は時空平面上で 勾配が異なり, 軌跡がいずれかの地点で交わり合い上流 端で流入順に番号をつけても, 下流側ではその順番が前 後し，立体的な表面を想定するのに無理が生ずる.そこ で, 追越が生じたとき, すなわち時空平面上で走行軌跡 が交差するたびに追越した車が追越された車と流入順に 付けられた番号を交換できるものと考える.すなわち， いま流入番号 $i$ の車のとき $t$ における道路上の位置を $x_{i}(t)$ とすれば常に下記の関係が成り立つものとする.

\section{$x_{i+1}(t) \leqq x_{i}(t)$}

図一6で実線で示す走行軌跡は式（1）に従って描い た軌跡図である。このような考えに従えば, どのような 交通流に対しても, 時間軸 $t$, 距離軸 $x$ および累加台 数軸 $n$ を与えることにより, 図一7に示すような交通流 の 3 次表示を考えることが可能となる.すなわち, 等高 線 $n(x, t)=i$ が軌跡 $x_{i}(t)$ である表面 $n(x, t)$ を交通表 面と考えるわけである. いま道路のある地点 $x=x^{(1)}$ を 想定すると, $x=x^{11}$ と交通表面, $n(x, t)$ との交わりは, 図一7で一点鎖線で示されるように地点 $x^{11}$ における累

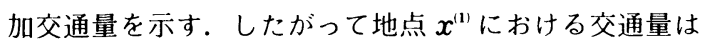
階段状の累加台数の頂点を結ぶ曲線の傾きで表わされる ことになる. 同様に任意の時刻 $t^{\prime \prime}$ における交通表面と の交わりの傾きが交通密度を与える.

ここで図一7で示したような階段状の 3 次元表面を各 走行軌跡を滑らかに摺付けて得られる, 連続した交通表 面を想定する。いま図一8に示すような任意の時間带と 区間で定められる時空平面上の領域 $A_{n}$ を考える. $A_{n}$ に対応する 3 次元交通平面を $A$ とする.ここで

$x_{i}$; 領域 $A_{n}$ における $i$ 番目の車の走行距離

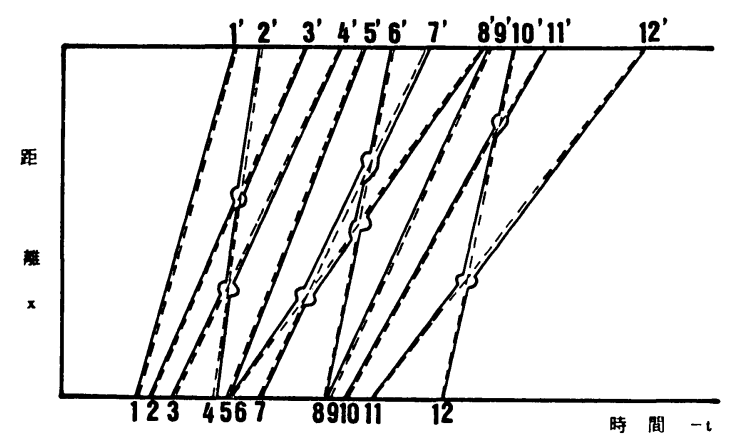

図一6 $x-t$ 座標上の各車の軌跡

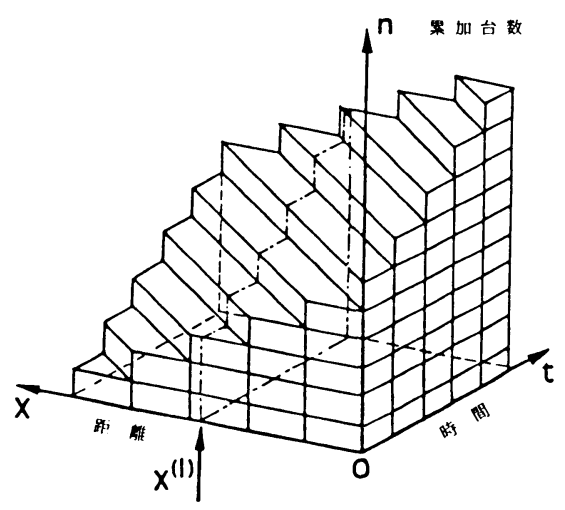

图一7 距離, 時間, 累積台数 3 次元表示

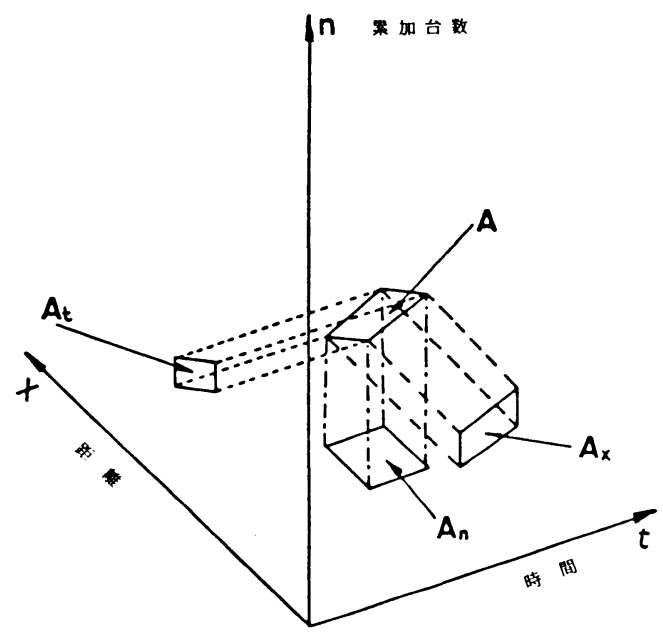

図-8 3 次元投影図

$t_{i}$; 領域 $A_{n}$ における $i$ 番目の車の走行時間 とすると, 領域 $A_{n}$ における交通量 $q$, 密度 $k$, 速度 $v$ の平均値は

$$
\begin{aligned}
& q=\Sigma x_{i} / A_{n} \\
& k=\Sigma t_{i} / A_{n} \\
& v=\Sigma x_{i} / \Sigma t_{i}
\end{aligned}
$$


で示される。いま地点 $x \sim(x+d x)$ の間を 1 時間に通 過した台数を $q$ とすれば,この場合の $A_{n}$ は 1 (時間) $\times$ $d x$ でありすべての通過車両のこの領域内の走行距離は $d x$ であるので, この場合式（2）の平均交通量に関す る定義式に上記を代入すれば,

$\Sigma x_{i} / A_{n}=q \cdot d x / d x=q$

となり, 地点 $x$ における交通表面 $A$ の傾きが交通量を 与えるとした図一7の定義と一致することになる. 密度 についても同様の関係を導くことが可能である.

さて, 図一 8 に示すように, 交通表面 $A$ の $n-x$ 平面 上への投影を $A_{t}, n-t$ 平面上への投影を $A_{x}$ とする. いま $i$ 番目の車の軌跡の $n-x$ 平面への投影は長さ $x_{i}$, 高さが 1 の長方形であり, $n$ - $t$ 平面への投影は長さ $t_{i}$, 高さが 1 の長方形であると考えられる.したがって，

$$
q=A_{t} / A_{n}, \quad k=A_{x} / A_{n}, \quad v=A_{t} / A_{x}
$$

3. (2) で示した航空写真からの計測結果から各車両 の走行軌跡をプロットしていくことは可能であるが, 上 記の式（２）または（３）を用いて密度や速度のコンター 図を作成していくことが可能となるわけである.

\section{（2）演算論理}

3. (2) の集計方法で示したとおり約 5 秒間隔で撮影 された航空写真からおのおののスライドフィルムごと に, その撮影時刻とその時刻における車两の走行位置と 車種が, 車線ごとに整理集計されている. 各車両には調 査区間へ流入してきた順に従って番号が付けられてお りそそれ゙れの車両番号ごとにフィルムの撮影時刻を 追って走行位置を追跡していけば走行軌跡を描くことが 可能である.このような基礎資料から式 ( 2 ) および ( 3 ) を利用して, 調查区間の速度や密度の変動状海を追跡し ていく電算プログラムの概要を以下に示す.

まず調査区間を等しい長さの区間に分割し，上流側か ら区間 1 , 区間 $2, \cdots \cdots$ 区間 $N$ と番号付けを行う. 区間 境界を測点とし，これも測点 1 , 测点 $2, \cdots \cdots$ 測点 $N$ の ように番号付けを行う. また解析時間帯を等時間の時間 帯に細分し, 距離軸之同様に時間帯 1 , 時間帯 $2, \cdots \cdots$ 時間帯 $M$ と番号付けを行う. 時間帯の境界を時刻点と し, 時刻点 0 , 時刻点 $1, \cdots \cdots$ 時刻点 $M$ と番号付けを

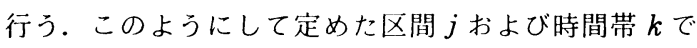
定められる時空平面上の領域を領域 $(j, k)$ と定義つ ける. 以下に領域 $(j, k)$ の平均交通量, 平均密度, 平均速度の計算方法を示す.

なお，この領域 $(j, k)$ の時空平面上での広がり， 具体的には区間長と時間帯の幅をどのような値にとるべ きかについては, 調査の目的や調䍒区間の特徵によって 異なってくるものと考えられる. しかし本研究では解析 手法の開発を 1 つの目的としているので，先に示した交 通密度の集計単位に合わせ, 区間長を $50 \mathrm{~m}$, 時間帯幅
を 3 分にとっている.

さて

$f_{n}: n$ 番目のフィルム番号

$t_{n}$ : 開始時刻からフィルム番号 $n$ までの時間

$t_{d}$ : フィルム番号 $f_{n}$ と $f_{n-1}$ の時間間隔

$y(j):$ 测点 $j$ の位置

$t(k)$ : 開始時刻から時刻点 $k$ までの時間

$z f_{n}(i)$ : フィルム番号 $f_{n}$ のときの $i$ 番目の車の位 置

$x_{i}(j, k):$ 領域 $(j, k)$ 内の $i$ 番目の車の走行距離 $t_{i}(j, k)$ : 領域 $(j, k)$ 内の $i$ 番目の車の走行時間 $\xi_{i}(j, k): i$ 番目の車の領域 $(j, k)$ への進入位置 $\xi_{i}^{\prime}(j, k): i$ 番目の車の領域 $(j, k)$ 少らの流出位置 $\tau_{i}(j, k): i$ 番目の車の領域 $(j, k) \sim$ 進入時間 $\tau_{i}^{\prime}(j, k): i$ 番目の車の領域 $(j, k)$ からの流出時間 とし，図一-9の(1)よび(2)で示す2つのケースについて 考える.

1) 車両が領域内を時刻点を越えすに通過する場合 (ケース(1)), 領域 $(j, k)$ 内の $i$ 番目の車の走行距離は, 測点間の距離となる.よって

$x_{i}(j, k)=y(j+1)-y(j)$.

いま, $z f_{n-1}(i)<y(j) \leq z f_{n}(i)$ となるフィルム番号 $f_{n}$ を選定し, 領域 $(j, k)$ への進入時間 $\tau_{i}(j, k)$ の計算を次 式で行う.

$$
\tau_{i}(j, k)=t_{n-1}+\frac{y(j)-z f_{n-1}(i)}{z f_{n}(i)-z f_{n-1}(i)} \cdot t d
$$

同様に, $z f_{n^{\prime}-1}(i)<y(j+1) \leq z f_{n^{\prime}-1}(i)$ となるフィルム番 号 $f_{n}$ を選定し, 領域 $(j, k)$ からの流出時間 $\tau_{i}^{\prime}(j, k)$ の計算を式 (5) で行う.

よって走行時間は次のようになる.

$t_{i}(j, k)=\tau_{i}^{\prime}(j, k)-\tau_{i}(j, k) \cdots$

2）時刻点を越えて通過する場合（ケース(2)

i ) 領域 $(j, k)$ について

領域 $(j, k)$ への進入時間 $\tau_{i}(j, k)$ は式 $(5)$ と同様 に計算される. また, 流出時間 $\tau_{i}^{\prime}(j, k)$ は時刻点 $(k+1)$

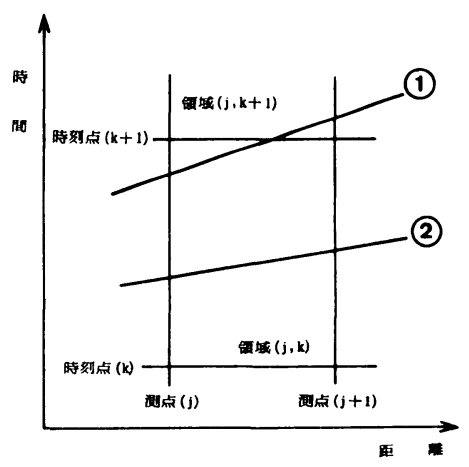

図一9 走行軌跡に基つく演算論理 
での時間となる．よって走行時間 $t_{i}(j, k)$ は次のように なる。

$t_{i}(j, k)=t(k+1)-\tau_{i}(j, k)$

次に, 領域 $(j, k)$ への進入位置 $\xi_{t}(j, k)$ は測点 $(j)$ の位置となる．また， $t_{n^{\prime-1}}<t(k+1) \leq t_{n}$ となるフィル 厶番号 $f_{n}^{\prime}$ を選定し, 領域 $(j, k)$ からの流出位置 $\xi_{i}^{\prime}(j, k)$ の計算を次式で行う。

$\xi_{i}^{\prime}(j, k)=z f_{n^{\prime}}(i)-\left\{z f_{n^{\prime}}(i)-z f_{n^{\prime-1}}(i)\right\} \frac{t_{n^{\prime}}-t(k+1)}{t d}$

よって, 領域 $(j, k)$ 内の走行距離は次のようになる. $x_{i}(j, k)=\xi_{t}(j, k)-y(j)$

ii ) 領域 $(j, k+1)$ について

領域 $(j, k)$ からの流出時間 $\tau_{i}^{\prime}(j, k)$ および流出位置 $\xi_{i}^{\prime}(j, k)$ が, 領域 $(j, k+1)$ への進入時間 $\tau_{i}(j, k+1)$ および進入位置 $\xi_{i}(j, k+1)$ となる.

また, 領域 $(j, k+1)$ からの流出時間 $\tau_{i}^{\prime}(j, k+1)$ は, 式（5）により計算され, 流出位置 $\xi_{i}^{\prime}(j, k+1)$ は測点 $(j+1)$ の位置となる.

よって, 走行時間および走行距離は次のようになる.

$t_{i}(j, k+1)=\tau_{i}^{\prime}(j, k+1)-\tau_{i}(j, k+1)$

$x_{i}(j, k+1)=y(j+1)-\xi_{i}(j, k+1)$

以上の(1)，(2)の場合の計算を全車について行い, 領域 $(j, k)$ の総走行距離 $\sum_{i} x_{i}(j, k)$ と総走行時間 $\sum_{i} t_{i}(j, k)$ を求める.

3）交通量 $q$, 密度 $k$ および速度 $v$ の計算

前節で述べた式 (2) より, 次式のように計算を行う.

$\bar{q}(j, k)=\sum_{i} x_{i}(j, k) / A_{n}(j, k)$

$\bar{k}(j, k)=\sum_{i} t_{i}(j, k) / A_{n}(j, k)$

$\bar{v}(j, k)=\sum_{i} x_{i}(j, k) / \sum_{i} t_{i}(j, k)$

\section{(3) 演算結果とその評価}

(a) 入力デー夕

9 時 40 分から 10 時 10 分の間の撮影フィルムに記録 された車両についてのすべてのデー夕は，表一2に例示 されているように集計表の形に整理されている．前章で 示した演算論理に従って電算を進めるにあたって，すべ てのデータはダイレクトパンチを用いて直接磁気テープ に集録された，その手順は次のとおりである。まず表一 3の入力データ一覧表のフィルム・車線デー夕欄の フォーマットに従ってフィルム番号, 撮影時刻および車 線区分をテープに入力し，その直後に車両 60 台分の記 録スペースを用意し,当該車線に存在する車両について, 調查区間進入時点で走行していた車線の区分, 車両番号, 車種および車両の存在位置が, 表一3の車両デー夕 フォーマットに従って入力される. 当該車線のすべての 車両データが入力し終わった後は, 残余の記録スペース
はブランクとし，次の車線へ移り同様に入力を続けてい くこのようにして全フィルムの記録を磁気テープに集 録を終えた後, 演算論理に従って電算処理が進められる わけであるが, 表一3のフォーマットから計算すると 1 枚の航空写真から得られる情報量は走行と追越の両車線 分のみを取り上げても，80 欄の IBM データカードにし て 184 枚分の情報量に相当したことになっている.

（b）交通量の比較照合

図一10にビデオ撮影地点における走行車線の 3 分間 交通量の計測值の変動状況を示す．実線は再生ビデオ画 面から直接計数器を用いて目視計測した 3 分間交通量を 示し，鎖線は航空写真から集計した車両の走行位置デー 夕を前節の演算論理に従って電算処理して得た値であ る. 初期值設定上誤差の生ずる可能性のある最初の 3 分 間を除き，上記 2 種類の計測結果の差は土 1 台であり, 航空写真の解析結果が非常に精度のよいものであること が示されている．なお追越車線については，ビデオが路 側からの撮影であり，走行車線に大型車が走行した際の 計測ミスも考えられるので，この種の比較照合には適さ ないものと考え，同様の検討は行っていない，交通量の 変動特性については，3.（2）集計方法とその結果（図 一4)で述べたとおりである.

\begin{tabular}{|c|c|c|c|c|}
\hline $\begin{array}{l}\text { テータ } \\
\text { 以分 }\end{array}$ & 項 & 管名 & $\begin{array}{l}\text { Pतन } \\
\text { Pッn }\end{array}$ & 内 \\
\hline 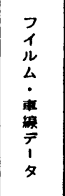 & 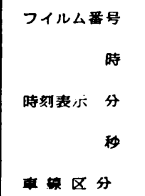 & \begin{tabular}{l|} 
N F \\
N H \\
N M \\
S \\
NKU
\end{tabular} & $\begin{array}{c}\mathrm{I3} \\
\mathrm{I2} \\
\mathrm{I2} \\
\mathrm{F} 5.2 \\
\mathrm{II}\end{array}$ & 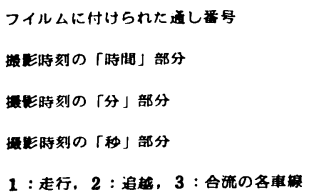 \\
\hline $\begin{array}{l}\text { 䎮 } \\
\text { 䎡 } \\
1 \\
\text { 夕 } \\
\mathrm{J}= \\
1 \sim 60\end{array}$ & 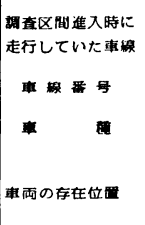 & $\begin{array}{l}\operatorname{MKU}(\mathrm{J}) \\
\operatorname{MN}(\mathrm{J}) \\
\operatorname{NSU}(\mathrm{J}) \\
\operatorname{AKP}(\mathrm{J})\end{array}$ & $\begin{array}{l}\text { I1 } \\
\text { I4 } \\
\text { I1 }\end{array}$ & 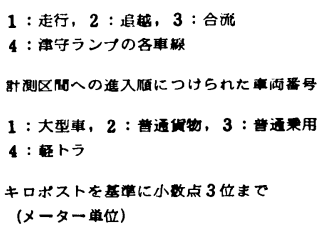 \\
\hline
\end{tabular}

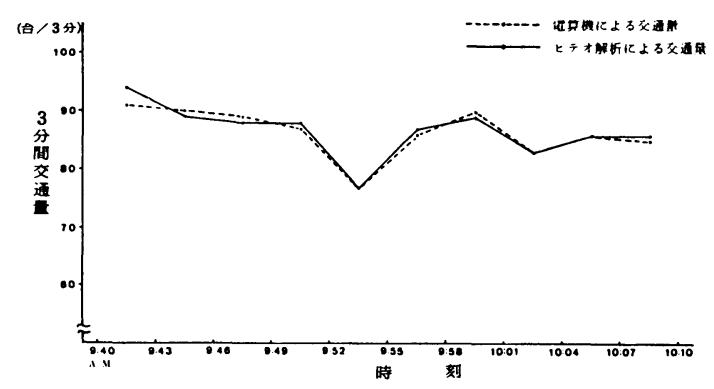

図一10走行車線の 3 分間交通贵变動図 
c) 密度・速度コンター図

図一11に航空写真からの集計值を電算処理して得た 交通密度のコンター図を走行車線, 追越車線および両車 線合計について示す．いずれのケースも区間と時間帯の 区分けは図一3の実測密度コンター図に一致させてい る. まず図一3に対応する図一11 (c) の両車線合計值 に注目すると, どの時間帯・区間も航空写真から直接求 めた実測と比べて,ほとんど同じ值を示し,その差はあっ

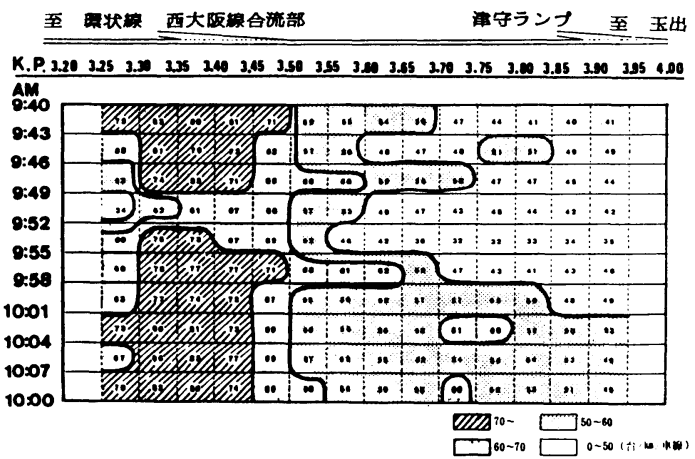

（a）電算処理による走行車線の密度コンター図

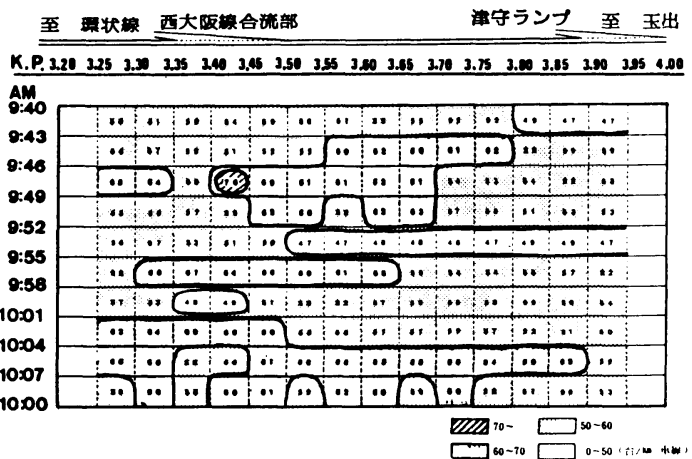

(b) 電算処理による追越車線の密度コンター困

至 状 西大阪綄合酼部

津守ンンフ 至 玉出
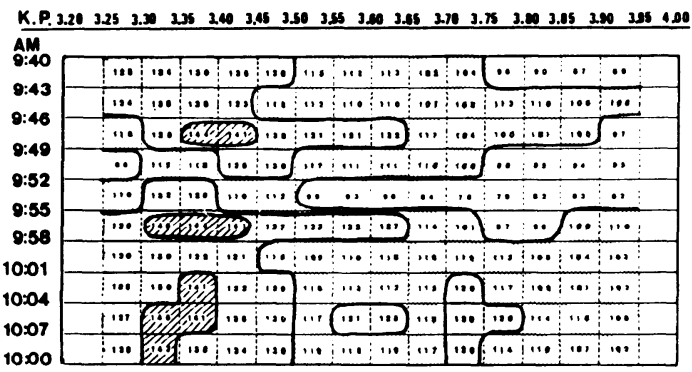

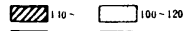

(c) 電算処理による走行・追越車線合計の密度コンター図

図-11
ても 5 ないし 7 台 $/ \mathrm{km} / 2$ 車線程度であり，したがって コンター図の形状もほほ類似している. 式(4)から（8) にかけての演算は, 撮影時刻ごとに計測された車両の存 在位置を直線でつないでいくことによって, 各車両の走 行軌跡を追跡するものであった. したがって定常な交通 流においては問題はないものの, 撮影時刻の間に速度が 急変していくような非定常状態の場合は, 多少の誤差が 生じてくる可能性もあるのではあるが, $50 \mathrm{~m}$ の区間を

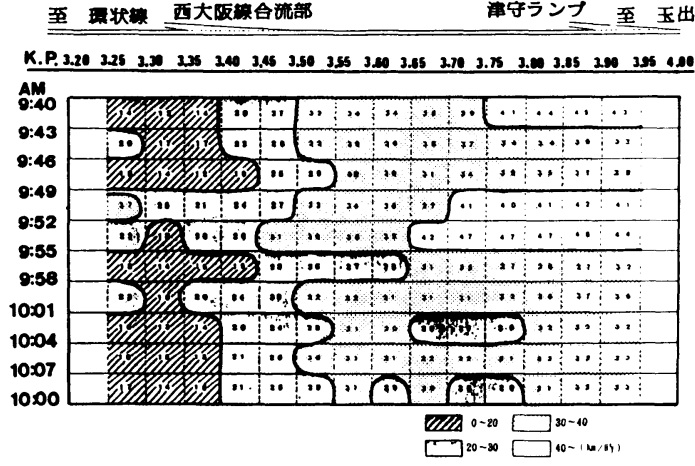

(a) 電算処理による走行車線の速度コンター図

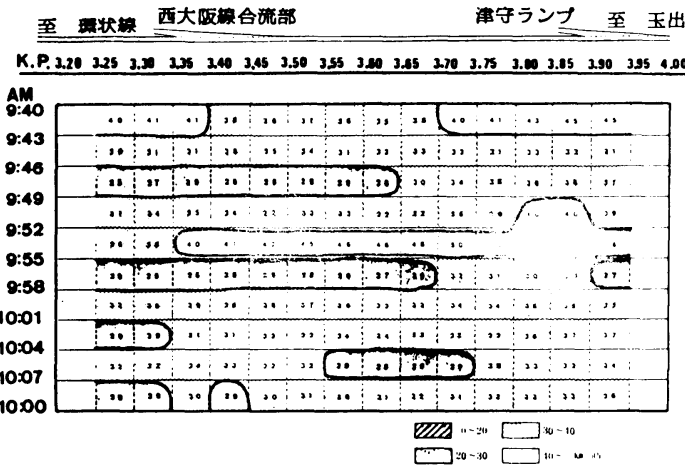

(b) 電算処理による追越車線の速度コンター困

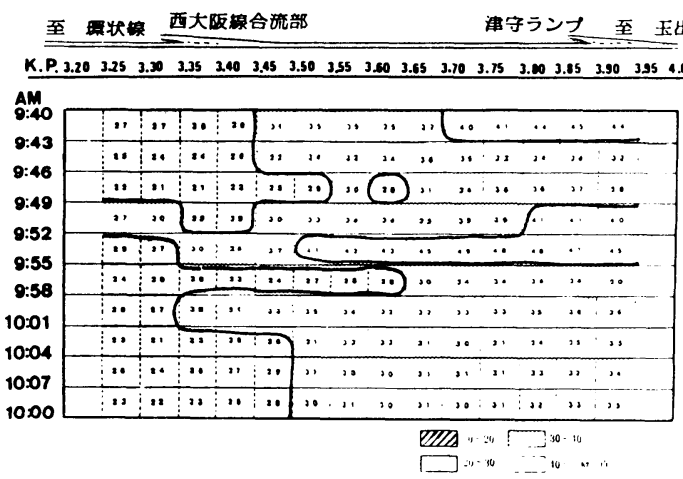

(c) 電算処理による走行・追越車線平均の速度コンター困

図-12 
A. M10:10

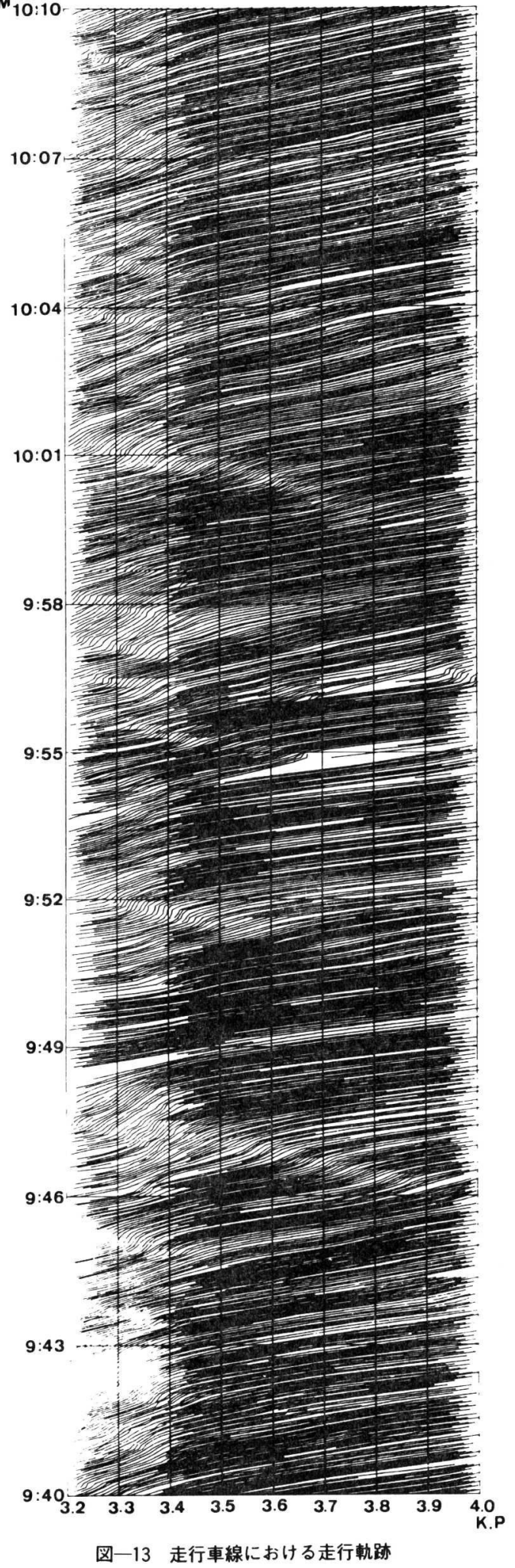

A.M

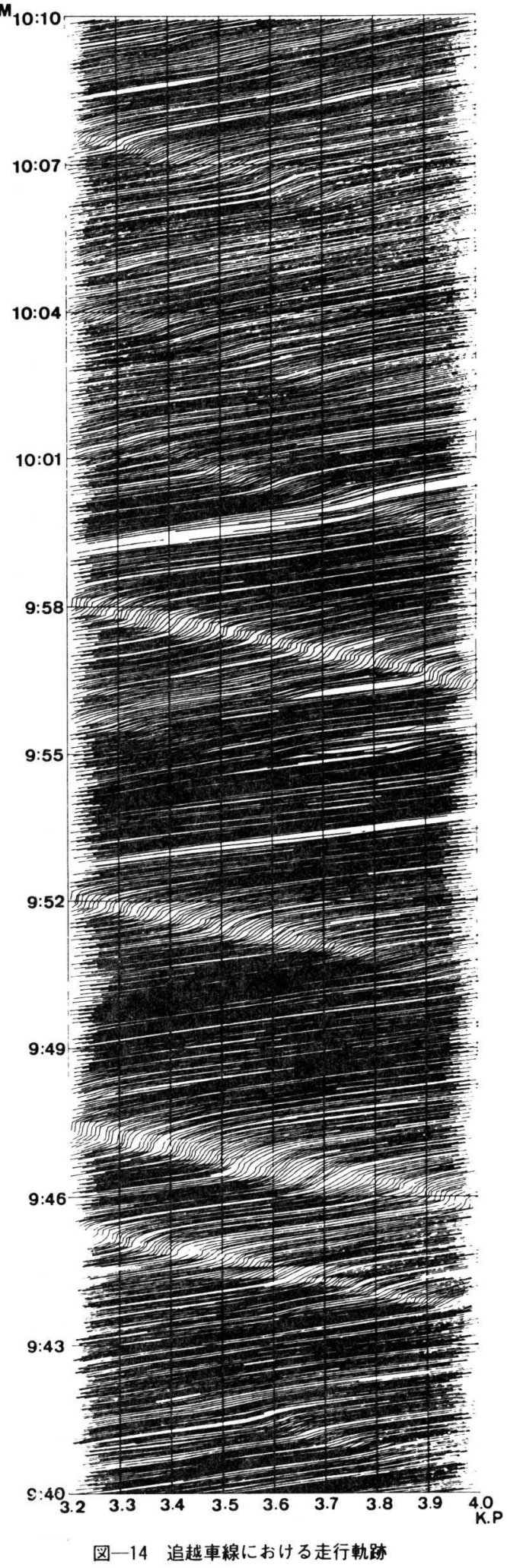


3 分にわたって平均した場合は、それほど問題とするよ うな差異もなく，妥当な結果が得られている.

一方車線別の密度の変動状況をみると, 追越車線は 50 台 $/ \mathrm{km} /$ 車線以上の比較的高密度の領域がほとんどを 占めているのに対し, 走行車線の交通密度は西大阪線か らの合流部の上流で 70 台 $/ \mathrm{km} /$ 車線以上の值となり, そ れより下流側は 60 台 $/ \mathrm{km} /$ 車線以下となっている. 明ら かに合流車両が加わり走行車線で超過需要が発生し, 渋 滞が上流側へ伝播している状態である. 一方この合流部 上流へ延伸した渋滞領域からは, 追越車線へ安定した飽 和交通流を送り込む結果を得ているものと考えられる. 以上のことは，図一12に示す速度コンター図でも同様 に指摘することができる. 特に追越車線の速度コンター 図で, ほとんどの領域で $30 \sim 40 \mathrm{~km} / \mathrm{h}$ の平均速度となっ ており交通容量よりも少々少ない交通量ではあるが安定 した交通流が得られていることが示されている.なお, 追越車線上で 9 時 52 分〜 55 分にかけての高速度・低交 通密度, およびそれに続く密度の上昇と速度の低下現象 は, 9 時 52 分から 55 分にかけて作業車が路側ビデオ撮 影地点付近の走行車線上に停車し, 交通を堰止めた影響 であると考えられる.

d) 走行軌跡図

図一13および図一14に, 走行車線および追越車線の 時空平面における全車両の走行軌跡を示す. 航空写真解 析上, 軌跡は車が写真に初めて現われた地点から最後に みえなくなるときまでが示されている．また車線変更は 軌跡が途中で始まるか, 途中で終わるかによって示され る.これらの軌跡に異常なものが見当たらないことによ り, 本調査研究の集計方法と演算処理に大きな誤りはな かったものと考えられる.走行軌跡図を全般的にみると, 流れがスムーズなときは均一で薄暗い領域が広がってい るのに対して, 速度の低下した部分では軌跡が立ち上が るため空白部分が目立つようになってくる. 速度・密度 の両コンター図とは逆の陰影となっているが, 渋滞領域 の変動状況はよく一致している.

特に注目したいのは追越車線上, 下流側から上流へ向 かう一過性のショックウェイブである. 9 時 51 分頃 $3.8 \mathrm{kp}$ 付近から発生したショックウェイブは車間距離 が異常に小さくなりブレーキをかけた車から後続して発 生したものと考えられる. また 9 時 44 分, 同 46 分およ び同 57 分下流端から発生したショックウェイブは, 調 查区下流側にある津守ランプから合流車を避けるため, 追越車線に割り込んだ車の影響等で発生した局部的な停 滞が原因と考えられる. いずれにせよ追越車線が飽和状 態であるため, ショックウェイブは最上流にまで波及し てはいくものの乱は一過性で, 調査区間全体が長時間停 滞してしまうまでには至っていない。ただしこの区間
の追越車線を走行している運転者がこのショックウェイ ブに出合うと, どこからこの渋滞が発生しているのか, わからなくなってしまうのであろう.

\section{5. 結論と今後の課題}

\section{（1）結 論}

本調査研究は渋滞の頻発する阪神高速道路堺線の西大 阪線合流部・津守入路下り区間において, ビデオ撮影, フローティング調査およびへリコプターによる上空固定 位置からのスチールカメラ撮影の 3 種類の調査を主とす る交通実態調查を行い調查対象区間の交通流の実態把握 を行うとともに，当該区間から発生すると考えられてい た交通啮滞の発生のメカニズムを追求することを目的と したものである．調査対象区間は $700 \mathrm{~m}$ を越える延長 を有しており，個々の車両の動きを詳細に追跡していく には延長があり過ぎて, 通常のビデオ撮影あるいはメモ モーションカメラによる調査は困難であり、ヘリコプ ターからの上空固定地点スチールカメラ撮影を主にし， 調査を進め，ビデオ撮影によって精度をチェックする方 法を取らざるを得なかった。調查は調査技術上および橴 滞原因の追求の両面からみて, 非常に良好な結果をもた らしていると結論づけることができる．以下に結論を両 観点に分けて示す。

調査技術上からみた結論

（1）秒単位の時刻を記録したへリコプターからの上 空固定地点スチールカメラ撮影による $35 \mathrm{~mm}$ スライド フィルムから各フィルムごとに車線別に各車両の走行位 置を読み取り，この結果を 3 次元立体交通モデルの理論 に基ついて解析した本調查の解析手法は調查対象区間の 任意の地点における交通量の計測を十分な精度で行うこ とができることを示した。これは航空写真の解析結果と 路側ビデオ撮影の計測結果を比較照合した結果, 初期値 設定上誤差の見込まれる初めの 3 分間以外は両者の計測 数の差は土 1 台であることから確かめられたことである (図-10参照).

（2）航空写真の計測結果に上記理論に基づいて電算 処理を加え, 走行・追越の各車線, および両車線合計の 3 種類の密度コンタ一図を作製し、これと航空写真から 直接作製した密度コンター図と比較した結果, 電算処理 結果は実測値と非常によく類似した結果を示した（図一 4 および図-11 (c) 参照).

（３）航空写真の計測結果から調査区間へ流入した全 車両の時空平面上における走行軌跡を電算処理によって プロットさせた結果, 合流部における速度の低下状況や 追越車線上での衝撃波の伝播状況等を明瞭に図示するこ とができた(図一13参照).

上記の調査結果から本調査区間内から発生する渋滞の 
原因と調査区間における交通流の特徵は次のとおりであ る.

（1）本調査区間から発生する橴滞の原因は西大阪線 合流部からの合流交通である. 西大阪線から来る車両と 堺線の走行車線を走行してきた車両が合流して合流区間 上の走行車線が過飽和状況となり合流部での速度低下上 流への渋滞の伝播という事態をまねいていることは, 密 度コンター図(図一11(a)), 速度コンター図(図一12(a)) および走行軌跡図(図一13,14)からみても明らかである.

（2）上記に示した西大阪線からの合流による渋滞 は，合流部の上流に橴滞領域を延伸させていき，この橴 滞領域からは調査区間の追越車線へ安定した飽和交通流 を送り込む結果となっている．したがって下流側の津守 入路付近で合流車を避けるため追越車線へ割り込んだ車 の影響等で局部的な停滞が発生すると, 飽和交通流であ るために一過性の衝撃波となり上流側へ伝播していく事 態か頻発している．津守〜西大阪線合流部の間で位置が 確定しがたい橴滞が発生しているといわれていたのは, この一過性の衝撃波を指していると結論づけられる.

\section{（2） 今後の課題}

上述したように本調查研究において, 調查技術の面か ら，また橴滞原因追究の面からも新たな知見を得たわけ であるが，今後さらにこのような課題に取り組んでいく 際の残された問題点としては次のようなことが揚げられ よう.

\section{(1) 解析時間帯の拡大}

今回の解析時間带である午前 9 時 40 分から午前 10 時 10 分の間では，すでにその前で䠈滞は始まっており， さらに混雑していく傾向にあると考えられる.したがっ て，橴滞の動きを明確にしていくためには，さらに前後 に時間を拡張して解析を続けていく必要があると考えら れる.

（2）交通流特性の追究
今回の解析では, 密度・速度のコンター図と走行軌跡 図の作成に主眼が置かれたが, 磁気テープにインプット されたデータをもとに，さらに $Q-V$ 特性や $K-V$ 特性, あるいは橴滞の発生と車線変更の関係等多椂な解析も可 能であり,この方面での解析手法の開発も望まれるとこ ろである。

（3）解析手法の能率化

ヘリコプターから撮影した $35 \mathrm{~mm}$ スライドフィルム の解析には非常に長い時間を要し, わずか 30 分の解析 に 2 か月余りの期間を費やすことになった．上記（2） で述べたように，さらに解析を梁めていくためにも，航 空写真フィルムからの集計作業の能率化を考えていく必 要があるものと考えられる.

最後に本調查研究を進めていくうえで多大の援助とご 協力をいただいた阪神高速道路公団に心からの謝意を表 したい。

\section{参考文献}

1) Allen, B. L. and May, A. D. : System Evaluation of Freeway Design and Operations; The Institute of Trans. portation and Traffic Engineering, University of California, July, 1969.

2) Cyra, D. J. : Traffic Data Collection Through Aerial Photography, Highway Research Record No. 35, pp. 28 29, 1971.

3) Makigami, Y. and Newell, G.F. : Three-Dimensional Representation of Traffic Flow, Transportation Science, Vol. 5, No. 3, pp. 302 313, August, 1971.

4) 阪神高速道路公団：阪神高速道路の交通啮滞対策に関す る調查研究報告書, (社)交通工学研究会, 昭和 56 年 3 月.

5) 首都高速道路公団：首都高速道路 6 号線二期及び葛飾川 線の部分供用に伴う交通状沇調查に関する報告書, 昭和 56 年 3 月.

6) 巻上安爾・林 昌親：航空写真による交通流の計測方法 について, 第 38 回土木学会概要集, 昭和 58 年 9 月.

(1983.11.28 • 受付) 